\title{
Varietal screening of rice against green leaf hopper, Nephotettix virescens distal
}

\author{
A. M. Kakde* and K. G. Patel ${ }^{1}$
}

Department of Entomology, N. M.College of Agriculture, Navsari Agricultural University, Navsari (Gujarat) India ${ }^{1}$ College of Agriculture, Bharuch (Gujarat) India

\begin{tabular}{|c|c|}
\hline ARITCLE & INFO \\
\hline Received & : 20.01.2018 \\
\hline Revised & : 08.03 .2018 \\
\hline Accepted & : 16.03 .2018 \\
\hline
\end{tabular}

KEY WORDS :

Green leaf hopper, Resistant,

Susceptible

*Corresponding author: amoljau@gmail.com

\begin{abstract}
The findings on per cent hill damage due to green leaf hopper indicated that GR-101, GR-102, GR-103, and GR-104 found resistant (R) and recorded per cent hill damage between 1 to 10 per cent. While, variety IR-28, GR-11 and Masuri were categoried as susceptible (S) as well as Gurjari and Jaya were grouped into the highly susceptible category (HS).
\end{abstract}

How to view point the article : Kakde, A.M. and Patel, K.G. (2018). Varietal screening of rice against green leaf hopper, Nephotettix virescens distal. Internat. J. Plant Protec., 11(1) : 46-50, DOI : 10.15740/HAS/IJPP/11.1/46-50. 